\title{
Strategic orientation and performance of agro-based firms in transition economy
}

\author{
Abiodun Abolaji Joachim* and Ibidunni Ayodotun Stephen \\ Department of Business Studies, Covenant University, P.M.B 1023, Ota, Nigeria.
}

Received 19 November, 2013; Accepted 11 June, 2014

\begin{abstract}
Strategic orientations indicate organizational leanings and approach to competition and competitive behaviours focused at achieving competitive advantages. This study explores the impact of strategic orientation dimensions on corporate performance of agro-business industry. The study based on questionnaires administered to selected Agro-based firms in Lagos and Ogun utilized descriptive statistics, Pearson's correlation to analyze the data obtained for the study. Results of data analysis showed that there exist positive relationship between strategic orientation dimensions and corporate performance. However, riskiness dimension was found not to correlate with financial and business dimensions of performance. The study recommend that the adoption of appropriate strategic orientation by agro-based firms to enhance their competitiveness and improve their overall operations.
\end{abstract}

Key words: Strategic orientation, strategic orientation dimensions, 'corporate performance, Agro-based firms, Strategy

\section{INTRODUCTION}

Strategic orientation involves the implementation of strategic directions that guide the activities of a firm to establish behaviours that achieve continuity in optimal performance for the business (Hakala 2010; Liu and Fu, 2011; Jeyakodeeswari and Jeyanithila, 2013). Understanding strategic orientation dimensions is important in revealing organization's chances and ability to align with environment (Choy and Mula, 2008) to secure competitive advantage for itself (Abiodun et al, 2011). Organizational strategic orientation aims at positioning it for superior performance and sustenance of competitive advantage above its rivals. The Nigeria Agro-business industry is fast gaining strategic focus due to the increased need and pressure to diversify nation's economy and also reduce the dependence of the country oil for her foreign earnings. The industry has massive potentials of economic benefits for the nation, in terms of creating employment opportunities and repositioning Nigeria as a major world exporter of basic food and industrial commodities in commercial quantities.

In terms of performance, evidences seem to point that the Nigeria Agro-business industry is being largely under-utilized (Ukeje, 1999; Manyong et al, 2005). Over 30 million hectares of Arable land is available in the nation. Reports hold that the agriculture sector with a growth rate of about $5.1 \%$ per annum is the slowest growing sector (Obinna, 2012). It is estimated that "by increasing yield and acreage, production growth rate may

\section{E-mail: a bijoach@yahoo.com Tel: +2348057626608}

Authors a gree that this a ricle remain pemanently open access under the tems of the $\mathrm{Creative} \mathrm{Commons}$ Attribution Lic ense 4.0 Intemational Lic ense 
rise to $160 \%$ by 2030 , rising from $\$ 99$ billion in 2010 to $\$ 256$ billion in 2030" (Alliance for Green Revolution in Africa - AGRA, 2012). Furthermore, there are evidences of failure in the integration of modern technological processes in the production of high value commodities. There also exist poor linkages between farmers and processors in the production processes which have resulted in the low productivity level of the industry. This can be attributed largely to inefficient integration of inputs, farm production and products processing (Uduji et al, 1994). Situations of unavailability of required funds, and the failure to channel funds to agro-business entrepreneurs when they are available are also major challenges to the sector. The foregoing points to the need for a strategic shift that will serve as problemsolving steps for re-positioning the industry; consequently, this study is focused on examining the strategic orientations dimensions that impacts on the performance of agro-based firms in Nigeria. This effort is both theoretically and empirically beneficial given the dearth of research efforts in this areas and the gap that this has created in literature. The link between strategic orientation dimensions and performance of the Agri-business industry in Nigeria is quite scanty. Therefore, this study aims at providing empirical facts to fill this gap.

\section{Strategic orientation dimensions}

Strategic orientation is a concept that has gained wide research attention either in the field of strategic management (example, Aragón-Sánchez and Sánchez-Marín, 2005; Slater et al., 2006; Choy and Mula, 2008; Liu and $\mathrm{Fu}, 2011$ ), or as an interdisciplinary concept involving entrepreneurial orientation, marketing orientation and learning orientation (example, Zhou et al., 2005; Arguelles and Bautista, 2007). Entrepreneurial orientation according to Lumpkin and Dess (1996), cited in Callaghan and Venter (2011) consists of five dimensions, namely, innovativeness, competitive aggressiveness, risk-taking propensity, autonomy and proactiveness. Boohene et al. (2012) suggest that Entrepreneurial orientation is a key driving force for a free market economy, thereby having a major influence on the demand and supply factors of the economy. Mehrdad et al, (2011) suggests that Entrepreneurial Orientation can be considered as the processes, practices, philosophy, and decision-making activities that lead organizations to innovation. A marketing orientated approach suggests that the business reacts to what customers want. The decisions taken are based around information about customers' needs and wants, rather than what the business thinks is right for the customer. Studies that revolve around market orientation emphasis the important role of customer satisfaction in achieving greater customer loyalty, which in turn result in better organizational performance (Hassan, 2012).
Learning organizations can be described as "organization skilled at creating, acquiring and transferring knowledge, and modifying its behaviour to reflect new knowledge and insights" (Ngesu et al, 2008). The increasing competitiveness and pressing need to establish competitive advantages through innovations has resulted in considering learning a major stimulus to firm's innovativeness (Ma'atoofi and Tajeddini, 2010). On an increasing basis "organizational researchers realize that an organization's learning capability will be the only sustainable competitive advantage in the future" (Yang et al., 2004). Farrell (1999) identified antecedents of learning orientation to include structure and environment. The structural connotation holds that organization with decentralized structures and share information by elimination all constraints to information flow will be more learning oriented than highly centralized and formalized structures. Three environmental variables impact on learning organizations: market turbulence, competitive intensity and technological turbulence.

\section{Theoretical perspectives of strategic orientation}

Miles et al. (1978) developed a theory based on an indepth cross-industry study and suggested that there are three superior performing business types and all others are average or less than average. Their theory holds that in order to be superior, there must be a clear and direct match between the organization's mission/values (their definition), the organization's strategies (their basic strategy set), and the organization's functional strategies (their characteristics and behavior) Kulzick (2000). Four typologies of organizations were identified as respondents to these problems: prospectors, defenders, analyzers and reactors. Prospectors are highly innovative firms constantly engage in a search for new opportunities and markets through a continuous process of experimenting with potential responses to emerging environmental trends (Barney and Griffin, 1992). They are growth and risk oriented. They are also identified as "creators of change and uncertainty to which their competitors must respond" (Miles et al., 1978 cited in Gimenez, 2000). Specific strategic characteristics that Kulzick (2000) identified with prospectors include: changing structure and technology, technologies in people not machines, planning is broad not intensive, product based structure, less division of labour and low formalization, complex and expensive coordination. Defenders concentrate on protecting their current narrow product-market. They show little concern about any outside search for new opportunities and rather pay attention to maintaining stable growth and improving efficiency in their current market. It is not unlikely that firms operating with a prospector strategy will switch over to a defender strategy. They are also characterized by stable structures and processes, in depth rather than 
extensive or broad planning, and centralized control. Analyzers are firms that combine the prospector and defender types of strategies. They engage efforts to minimize risk while maximizing profit opportunities, therefore picking on the strength of both the defender and prospector. Reactors exhibit a pattern of inconsistent and unstable adjustments to their environment. Most often, the reactor strategy arises as a result of improper implementation processes in one of the other three strategies. Organizations that fall into this category are likely characterized by ambiguous strategies, lack of the strategy - structure relationship, and the failure to link up such relationship with environmental changes.

Porter (1980) explained three "generic strategies" in his book Competitive Strategy: Techniques for Analyzing Industries and Competitors. These strategies provide important support to outperform competitors keeping in view the five competitive forces. The generic strategies are: Overall cost leadership, differentiation and focus strategies. Overall Cost Leadership, strategy targets incurring the lowest possible cost relative to competitors. This strategy therefore requires management concentration on cost minimizing and control measures and an aggressive implementation of efficiency of scale in production, supply and distribution, advertising, research and development, sales force, and so on. This strategy can be achieved through managerial experience, well implemented functional policies targeted at this purpose, high market share, proximity to raw materials, and so on. However, the operationalization of the strategy must not assume a reduction on quality, required customer service and other important aspects. The overall cost leadership strategy comes with gains such as above average returns despite tough industry competition. It also protects the firm against the five competitive forces. However, the demands of achieving an overall cost leadership include heavy investment in updating technology, aggressive pricing and likelihood of trading off initial profit margins to gain high market share. Differentiation strategy is one that presents "the product or service offering of the firm, creating something that is perceived industry wide as unique". Differentiation for a firm can be applied along different dimensions, for example, a company's product, say a car manufacturer that involves different component can be differentiated along these component dimensions. Although, differentiation sometimes can come with high cost demands, it is beneficial for achieving above average returns. Focus strategy involves giving attention to a particular buyer group, segment of the product line, or geographic market. Unlike the first two strategies discussed, the focus strategy concentrates on serving a particular market group very well rather than achieving industry wide objectives. A firm operating on the focus strategy can either engage in differentiating its products for its served, market or achieve overall cost leadership. Alternatively it can achieve both.
In 1989, Venkatrman proposed a set of strategic orientation variables that are applicable at the business level. Popularized as "STROBE": Strategic orientation of business enterprises, this dimension consists of six items. They are: aggressiveness, analysis, defensiveness, futurity, proactiveness and riskiness. Aggressiveness dimension measures the business ability to engage organizational resources in executing aggressive strategies and the pursuit of increased market share as a means to achieving business unit profitability. The aim of the firm is to possess higher market share ahead of competitors (Abiodun, 2009). This strategy takes the form of cost leadership (Porter, 1980; Miller 1988; Wright et al 1992; Thompson and Strickland, 1999; Hitt et al, 2007; Chang et al, 2002), explosion and expansion strategy described by Wissema et al (1980), product innovation (Schuler and Jackson, 1987; Miller, 1988), price and image differentiation (Mintzberg, 1988). Analysis refers to the ability to investigate deeply into the foundational causes of problems and develop the best alternative solution as a way of problem-solving. It relates to the maintenance of internal consistency in the resource allocation strategies towards the achievement of corporate objectives. The alignment of resource allocation and competitive intelligence are important issues of consideration (Abiodun et al, 2011). Defensiveness reflects the firm's emphasizes on defense strategies over its core technology and product-market domain through the use of cost minimization and techniques that achieve operational efficiency. This posture is related to the defender trait described by Miles et al. (1978), defensive actions (Miles and Cameron, 1982), niche marketers (Miller, 1988), cost reduction (Schuler and Jackson, 1987) and niche differentiation (Ward et al, 1996). Futurity is the extent to which decisions that relate to possible future occurrences are seriously engaged. It reflects issues like sales forecast, possible changes in customer preference, and tracking of environmental changes. It is manifested by a firm's incorporation of its vision of the vision as a strategic concern (Stambaugh et al, 2011). Proactiveness reflects the firm's constant engagement in the search for new market opportunities, the first mover in the introduction of new products, while old products are strategically withdrawn from markets. It shows the degree of the firm's experimentation with marketing research responses (Venkatraman, 1989). It explains a firm's drive for first mover position in the market (Chang et al, 2002), and a search for new opportunities (Miles et al., 1978), and the pursuit of new markets through the engagement of value innovations. Riskiness captures the extent of riskiness of the firm. This is reflected in its choice and criteria over resource allocation decisions and the general pattern of decision making. Firms characterized with high risk strategies may be trading-off with lower profits than expected (Söderbom, 2012).

This research paper adopts the STROBE dimension 
introduced by Venkatraman (1989). The justification for this is contained in the fact that unlike other dimensions that basically classify strategy, STROBE view strategic orientation along specific dimensions which are common to all firms (Morgan and Strong, 2003).

\section{Strategic orientation dimensions and corporate performance}

Fauzi et al. (2010), defined corporate performance as the organization's ability to attain its goals by using resources in an efficient and effective manner. The performance of organizations consists of both qualitative and quantitative factors (Popova and Sharpanskykh, 2010), such as profit, cost, number of clients, and so on. Liu and Fu (2011) observed the varying relationships between strategic orientation and performance from one organization to another, therefore in cases where no direct relationship is found, they suggest a moderating and mediating effect. In their opinion, a moderator "explains how the dependent variable is affected by independent variables". Therefore, moderating effect reveals that existing causal relationships between two variables will vary as the moderators assume different values. Mediators on the other hand show the "internal reason between independent variable and dependent variable". In another study Slater et al. (2006), demonstrated that strategic orientation itself could serve as a moderating influence in the relationship between elements of strategy formation capabilities and performance.

\section{MATERIALS AND METHODS}

The research made use of the survey research design. A cross sectional design was adopted. A sample size of 210 agro-based firms was surveyed of an estimated population of about 1500 registered agro based firms in the study locations. This represent $14 \%$ of registered Agro based firms in the study area. The sampling techniques adopted for this study include convenience sampling and the purposive sampling. The justification for this sampling approach in anchored on respondents' unwillingness to supply information in some of the firms intended for the study and non-response from others to consent to use the firm. Therefore, participants and firms willingness to participate in the study was a key issue for inclusion in the sample. A major advantage of the chosen sampling techniques is that they produced an unbiased answer from respondents and openness to follow-up interview where clarifications were required.

Furthermore, the choice of the study area was largely influenced by cost of survey, time, logistic problems and accessibility. However, sampling within the organizations involved the use of stratified sampling approach as well as purposive sampling. In each of the sampled organization the top hierarchies form strata which were purposefully sampled to include key organization officers. This is due to the fact that strategic issues demand the attention of well-trained officers which are usually located at the top echelon within the organization. Low cadre officers, below the rank of manager were excluded from the sample. Data used for this study was obtained from both primary and secondary sources.
The primary sources include the administration of questionnaires on: Managing Directors, Chief Executive Officers and Functional Managers of Agriculture producing firms. Most of the items in the questionnaire were adapted from the instrument developed by Venkatraman (1989), with modifications to suit the current need and industry of the study.

The instrument was organized into three sections, A to $C$. Section A contain the background information of the respondents. This was designed to capture the respondent's status, demographic information and eligibility to respond to the questions. Section $B$ focused on questions that are firm specific. It is focused on obtaining information relating to the characteristics and operations of the firm. It basically inquired into the date the company started operations and the number of employee presently serving in the organization. Section $\mathrm{C}$ dealt with questions that relate to the thrust of the study. The section is divided into two parts. The first section provides information that enables us to gain insight into the strategic orientations of the firms. Therefore, questions were focused on the basic orientations of aggressiveness, analysis, defensiveness, futurity, proactiveness and riskiness (Venkatraman, 1989). Each of these were scaled using a 5-point likert scale. The second segment focused questions on the performance variables. Following the works of Wang et al. (2010), three variables were adopted: Financial, business and effectiveness dimensions of performance.

A total of 193 questionnaires was retrieved and adjudged suitable, which formed the basis of the analysis in this study, which is $91.9 \%$ response rate.

\section{RESULTS AND DISCUSSION}

An analysis of the questionnaires by total responses showed that 50 respondents, that is $25.9 \%$ have less than 5 years working experience. 67 (34.7\%) obtain between 5 to 10 years working experience, while 29 $(15.0 \%)$ have experienced 11 to 15 years of working in the agricultural business. $47(24.4 \%)$ have worked in the business for 16 years and above. The largest number of respondents are those who are Managers in the organization, consisting of 96 of the respondents (49.7\%). 24 respondents (12.4\%) occupy positions of Chairman/M.D., while only 14 respondents (7.3\%) are CEO/Deputy M.D. Senior managerial position consists of 59 respondents (30.6\%). 170 respondents, that is $88.2 \%$ have a minimum of first degree while only 23 respondents $(11.9 \%)$ have less than first degree. This reveals that apart from experience gathered on the job a large number of respondents attained reasonable level of education to respond to the questionnaire. A large number of 108 firms, that is, $56.1 \%$ of the firms started before the year 2000. This reveals that majority of the firms are well established in the agricultural business. The remaining 85 firms (44.0\%) have existed from 2000 to date. 179 respondents $(92.7 \%)$ work in organizations with staff capacity of between 1 and 299. This shows that most firms in the agro-based business are small and medium enterprises. Only 14 respondents (7.3\%) work in organizations with 300 and above staff capacity

Table 1 shows the descriptive statistics of respondents on the various dimensions of strategic orientation dimensions. The table reflects the degree to which firms 
Table 1. Descriptive statistics of strategic orientation dimensions.

\begin{tabular}{lccccccc}
\hline & $\mathbf{N}$ & Mean & Std. Deviation & \multicolumn{2}{c}{ Skewness } & \multicolumn{2}{c}{ Kurtosis } \\
\hline & Statistic & Statistic & Statistic & Statistic & Std. Error & Statistic & Std. Error \\
\hline Aggressiveness & 193 & 3.9573 & .84227 & -.492 & .175 & -.667 & .348 \\
Analysis & 193 & 4.3506 & .43666 & -.973 & .175 & 1.845 & .348 \\
Defensiveness & 193 & 4.3109 & .55480 & -1.161 & .175 & 2.066 & .348 \\
Futurity & 193 & 4.1801 & .60189 & -.531 & .175 & -.201 & .348 \\
Proactiveness & 193 & 3.9870 & .73719 & -.861 & .175 & .834 & .348 \\
Riskiness & 193 & 3.2394 & .71159 & .314 & .175 & -.596 & .348 \\
Valid N (listwise) & 193 & & & & & & \\
\hline
\end{tabular}

Table 2. Descriptive statistics of corporate performance items.

\begin{tabular}{lccccccc}
\hline & $\mathbf{N}$ & Mean & Std. Deviation & \multicolumn{2}{c}{ Skewness } & \multicolumn{2}{c}{ Kurtosis } \\
\hline & Statistic & Statistic & Statistic & Statistic & Std. Error & Statistic & Std. Error \\
\hline Financial Performance & 193 & 3.9469 & .74658 & -.729 & .175 & .280 & .348 \\
Business Performance & 193 & 4.2263 & .63194 & -.896 & .175 & .677 & .348 \\
Org Effectiveness & 193 & 4.0743 & .78374 & -.839 & .175 & .689 & .348 \\
Valid N (listwise) & 193 & & & & & & \\
\hline
\end{tabular}

in the Nigeria agro-business industry engage each of the six dimensions of strategy in their business operations. It is evident that on a likert scale where 5 is the maximum, industry players give strong recognition and support to the role of aspects of strategic orientation. This also goes on to inform that there exists a high awareness of aspects of strategic orientation in the industry. The most prominently engaged strategic posture is the analysis orientation (mean $=4.35$ ). Arguments to support this claim could result from the fact that the agro-business industry is faced by several sever challenges that require firms to seek problem solving measures in order to survive the pressures of the industry (Ukeje, 1999; Manyong et al., 2005). There are also high engagements of defensiveness orientation (mean $=4.3$ ) and futurity orientation (mean $=4.2$ ). The implication of such defensive actions could be traced to the pressures faced by local industry players from their foreign counterparts. Therefore, firms strategically make efforts to secure their present product-market domain. Actions relating to future expansions and growth also gain the focus of the firms. However, firms seem not to be well inclined to the riskiness orientation (mean $=3.2$ ). The supporting evident for this can be explained by factors such as several failures in government support policies that could have aided the growth of the industry, the slow growth of the industry and the uncertainties that surround price control mechanisms and the Nigeria agricultural market (Grandval and Douillet, 2011; Obinna, 2012).

Table 2 shows the descriptive statistics of performance variables. The statistical figures for the multi-item index of each performance variable reflect the firms' competitiveness in the industry. The above table reflects an above average performance index. Business performance seem to be the most prominent aspect of optimal performance (mean $=4.2$ ). Policies that surround organizational effectiveness also seen to be given due consideration (mean $=4.1$ ). In other words, firms ensure that employee related policies, market share sustenance and expansion strategies and innovativeness gain good degree of management focus. Aspects of financial performance appear to be lowest (mean $=3.9$ ), but even at that is quiet high. Table 3 shows the correlation between the dimensions of strategic orientation and financial performance. The financial performance of the firm has a positive and significant correlation with the aggressive, analysis, defensive, futurity, and proactive dimensions of strategic orientation. However, financial performance has no correlation with the riskiness dimension. It holds that the riskiness trait of a firm does not necessarily result in higher financial performance.

Table 4 summarizes the correlation relationship between strategic orientation dimension and business performance. The results reveal that business performance has a positive impact on aggressiveness, analysis, defensiveness, futurity, and proacitveness strategic orientation dimensions. The conception about riskiness dimension shows that it does not have any relationship with business performance. In other words, the risk taking attribute of a firm does not necessarily lead to better business performance. Table 5 shows the significant relationship between strategic orientation 
Table 3. Zero-order correlation coefficient of strategic orientation dimensions and financial performance

\begin{tabular}{lccccccc}
\hline & $\mathbf{1}$ & $\mathbf{2}$ & $\mathbf{3}$ & $\mathbf{4}$ & $\mathbf{5}$ & $\mathbf{6}$ & $\mathbf{7}$ \\
\hline Aggressiveness & 1 & & & & & & \\
Analysis & $.385^{\star \star}$ & 1 & & & & & \\
Defensiveness & $.303^{\star \star}$ & $.559^{\star \star}$ & 1 & & & & \\
Futurity & $.443^{\star \star}$ & $.621^{\star \star}$ & $.456^{\star \star}$ & 1 & & & \\
Proactiveness & $.444^{\star \star}$ & $.330^{\star \star}$ & $.314^{\star \star}$ & $.578^{\star \star}$ & 1 & & \\
Riskiness & -.071 & $-.184^{\star}$ & $-.166^{\star}$ & $-.274^{\star \star}$ & -.124 & 1 & \\
Financial & $.188^{\star \star}$ & $.437^{\star \star}$ & $.379^{\star \star}$ & $.410^{\star \star}$ & $.270^{\star \star}$ & -.092 & 1 \\
\hline
\end{tabular}

** Correlation is significant at the 0.01 level (2-tailed)

* Correlation is significant at the 0.05 level (2-tailed)

Table 4. Zero-order correlation coefficient of strategic orientation dimensions and business performance

\begin{tabular}{lccccccc}
\hline & $\mathbf{1}$ & $\mathbf{2}$ & $\mathbf{3}$ & $\mathbf{4}$ & $\mathbf{5}$ & $\mathbf{6}$ & $\mathbf{7}$ \\
\hline Aggressiveness & 1 & & & & & & \\
Analysis & $.385^{\star \star}$ & 1 & & & & & \\
Defensiveness & $.303^{\star \star}$ & $.559^{\star \star}$ & 1 & & & & \\
Futurity & $.443^{\star \star}$ & $.621^{\star \star}$ & $.456^{\star \star}$ & 1 & & & \\
Proactiveness & $.444^{\star \star}$ & $.330^{\star \star}$ & $.314^{\star \star}$ & $.578^{\star \star}$ & 1 & & \\
Riskiness & -.071 & $-.184^{\star}$ & $-.166^{\star}$ & $-.274^{\star \star}$ & -.124 & 1 & \\
BusinessPerformance & $.251^{\star \star}$ & $.525^{\star \star}$ & $.456^{\star \star}$ & $.454^{\star \star}$ & $.328^{\star \star}$ & -.087 & 1 \\
\hline
\end{tabular}

** Correlation is significant at the 0.01 level (2-tailed)

* Correlation is significant at the 0.05 level (2-tailed)

Table 5. Zero-order correlation coefficient of strategic orientation dimensions and organizational effectiveness

\begin{tabular}{|c|c|c|c|c|c|c|c|}
\hline & 1 & 2 & 3 & 4 & 5 & 6 & 7 \\
\hline Aggressiveness & 1 & & & & & & \\
\hline Analysis & $.385^{\star \star}$ & 1 & & & & & \\
\hline Defensiveness & $.303^{\star \star}$ & $.559 \star \star$ & 1 & & & & \\
\hline Futurity & $.443^{\star \star}$ & $.621^{\star \star}$ & $.456^{\star *}$ & 1 & & & \\
\hline Proactiveness & $.444^{\star \star}$ & $.330^{\star \star}$ & $.314^{\star *}$ & $.578^{\star \star}$ & 1 & & \\
\hline Riskiness & -.071 & $-.184^{*}$ & $-.166^{\star}$ & $-.274^{\star \star}$ & -.124 & 1 & \\
\hline Org Effectiveness & $.422^{\star \star}$ & $.581^{\star \star}$ & $.565^{\star \star}$ & $.624^{\star \star}$ & $.381^{\star *}$ & $-.142^{*}$ & 1 \\
\hline
\end{tabular}

** Correlation is significant at the 0.01 level (2-tailed)

* Correlation is significant at the 0.05 level (2-tailed)

dimensions and organizational effectiveness. There is a significant positive relationship between aggressiveness, analysis, defensiveness, futurity, and proactiveness dimensions of strategic orientation and organizational effectiveness. The riskiness dimension also shows a relationship with organizational effectiveness, however, it appears to be a negative relationship. This implies that for every change in the risk taking attitude of the firm, there will be a significant decline in organizational effectiveness to the tune of $14 \%$.

\section{MANAGERIAL IMPLICATIONS AND CONCLUSIONS}

Findings from this study present empirical evidence that have significant implications to management. The findings of this study show the importance of strategic orientation dimensions to performance of corporate 
organizations. Firms can improve their business processes and achieve better effectiveness and efficiency through the engagement of strategic approaches. Firms that desire better financial performance may strive to adopt a strategic orientation that emphasize basic aspects of their income generation and management activities such as sales growth objective, investment decisions, employee productivity goals and net income growth. Businesses can also improve their, positioned their corporate image to attract professionals, and achieve better employee motivation by engaging strategic orientation. The study also revealed that strategic postures impact significantly on the effectiveness of organizations.

\section{REFERENCES}

Abiodun AJ, Osibanjo O, Oyeniyi O (2011). Strategic orientations and technology policy: An empirical test of relationship in developing countries, Manage. Sci. Lett. 1(3):315-322.

Abiodun AJ (2009). Exploring the Relationship Between Human Personal Values, Strategy Dimensions and Performance, Annals of University of Bucharest, Economic and Administrative Series (3):237-248.

Alliance for Green Revolution in Africa - AGRA (2013). An article published on www.thisdaylive.com, 13 June 2012, Retrieved 6 February.

Aragón-Sánchez A, Sánchez-Marín G (2005). Strategic Orientation, Management Characteristics, and Performance: A Study of Spanish SMEs, J. Small Bus. Manage. 43(3):287-308.

Arguelles R, Bautista R (2007). Strategic Orientation of Small Business Entrepreneurs in Baguio City, a paper presented at the $10^{\text {th }}$ National Convention on Statistics (NCS), EDSA Shangri-La Hotel, October 12, 2007.

Barney J, Griffin R (1992). The management of organizations: Strategy, structure, behavior, Houghton Mifflin, retrieved from http://web.ku.edu/ dsmgt310/SuppMaterial/MilesSnowTypology.htm

Boohene R, Marfo-Yiadom E, Yeboah M (2012). An empirical Analysis of the Effect of Entrepreneurial Orientation on Firm Performance of Auto Artisans in the Cape Coast Metropolis, Developing Country Studies 2(9). file:///C:/Users/sunny/Downloads/2970-5004-1-PB.pdf

Callaghan C, Venter R (2011). An investigation of the entrepreneurial orientation, context and entrepreneurial performance of inner-city Johannesburg street traders, Southern Afr. Bus. Rev. 15(1).

Chang SC, Lin NP, Wea CL, Sheu C (2002). Aligning manufacturing strategy with business strategy-an empirical study in high-tech industry, Int. J. Technol. Manage. 24(1):70-87.

Choy S, Mula J (2008). The Impact of Strategic Orientation Dimensions on Business Performance: A case study based on an international organization. http://eprints.usq.edu.au/6018/

Farrell M (1999). Antecedents and Consequences of A Learning Orientation, Market. Bull. 10(4):38-51. http://marketingbulletin.massey.ac.nz/V10/MB_V10_A4_Farrell.pdf

Fauzi H, Svensson G, Rahman A (2010). "Triple Bottom Line" as "Sustainable Corporate Performance": A Proposition for the Future, Sustainability 2:1345-1360.

Gimenez F (2000). Miles and Snow's Strategy Model In The Context Of Small Firms, Universidade Estadual de Maringá, Av. Colombo, Brazil. http://www.scribd.com/doc/221894508/Miles-Snow\#

Grandval F, Douillet M (2011). Nigeria's Agricultural Policy: Seeking Coherence Within Strategic Frameworks, Retrieved from http://www.inter-reseaux.org/revue-grain-de-sel/51-special-issuenigeria/article/nigeria-s-agricultural-policy?lang $=\mathrm{fr}$

Hakala H (2010). Configuring Out Strategic Orientation, Business Administration 95 Management and Organization, Universitas Wasaensis.
Hassan A (2012). Market Orientation Practices of Multinationals in Lagos, Nigeria, Int. J. Market. Stud. 4(5).

Hitt MA, Hoskisson RE, Ireland D (2007). Management of strategy: Concepts and cases. Australia: Thomson/South Western http://www.cengage.com/search/productOverview.do? $\mathrm{N}=+11 \& \mathrm{Ntk}=$ P_Isbn13\&Ntt=9781439042304

Jeyakodeeswari R, Jeyanithila R (2013). Impact of strategic orientation on women owned service enterprises, presented at the Tenth AIMS International Conference on Management January 6-9, 2013.

Kulzick R (2000). Miles and Snow, Organizational Types, An article retrieved from www.kulzick.com/milesot.htm

Liu B, Fu Z (2011). Relationship between Strategic Orientation and Organizational Performance in Born Global: A Critical Review, Int. J. Bus. Manage. 6(3).

Lumpkin GT, Dess GG (1996). Clarifying the Entrepreneurial Orientation Construct and Linking It to Performance, Acad. Manage. Rev. 21(1):135-172.

Ma'atoofi A, Tajeddini K (2010). The Effect of Entrepreneurship Orientation on Learning Orientation and Innovation: A Study of Small-Sized Business Firms in Iran, Int. J. Trade, Econ. Financ. 1(3).

Manyong V, Ikpi A, Olayemi J, Yusuf S, Omonona B, Okoruwa V, Idachaba F, (2005). Agriculture in Nigeria: Identifying Opportunities for Increase Commercialization and Investment, International Institute of Tropical Agriculture (IITA), Ibadan.

Mehrdad M, Abdolrahim S, Hamidreza D, Mohsen M, Ramin M (2011). Entrepreneurial Orientation and Innovation Performance: The Mediating Role of Knowledge Management, Asian J. Bus. Manage. 3(4):310-316.

Miles R, Snow C, Meyer A, Coleman H (1978). Organizational Strategy, Structure, and Process, Acad. Manage. Rev. 3(3):546-562. file:///C:/Users/sunny/Downloads/3deec517a93e495adb.pdf

Miles R, Cameron K (1982). Coffin nails and corporate strategies. New Jersey: Prentice-Hall.

Miller D (1988). Relating porter's business strategies to environment and structure: Analysis and performance implications. Acad. Manage. J. 31(2):280-308.

Mintzberg H (1988). Generic strategy: Toward a comprehensive framework. Adv. Strat. Manage. 5:1-67.

Morgan R, Strong C (2003). Business performance and dimensions of strategic orientation, J. Bus. Res. 56(3):163-176.

Ngesu L, Wambua B, Ndiku J, Mwaka M (2008), Universities as learning organizations: Implications and challenges, Educ. Res. Rev. 3(9):289-293.

Obinna C (2012). NIRSAL: Unlocking Nigeria's Agricultural Potentials, Retrived from http://www.thisdaylive.com/articles/nirsal-unlockingnigeria-s-agricultural potentials/117865

Popova V, Sharpanskykh A (2010). Modeling Organizational Performance Indicators, Inform. Syst. J. 35(4):505-527.

Porter M (1980). Competitive Strategy, Techniques for Analyzing Industries and Competitors, the Free Press, New York pp.34-40

Schuler RS, Jackson SE (1987). Linking competitive strategy with human resource management practices. Acad. Manage. Executive 1(3):207-219.

Slater S, Olson E, Hult T (2006). The Moderating Influence Of Strategic Orientation On The Strategy Formation CapabilityPerformance Relationship, Strat. Manage. J. 27:1221-1231.

Söderbom M (2012). Managerial Risk Attitudes and Firm Performance in Ghanaian Manufacturing: An Empirical Analysis Based on Experimental Data, CSAE-UNIDO Working Paper No. 3.

Stambaugh J, Yu A, Dubinsky A (2011). Before the Attack: A Typology of Strategies for Competitive Aggressiveness, J. Manage. Policy Pract. 12(1).

Thompson AA, Strickland AJ (1999). Strategic Management, Concepts and Cases, McGraw Hill Irwin; New York.

Uduji J, Oyaka J, Edicha M (1994). Strategic Marketing For Agricultural Produce In Nigeria, A web presentation retrived on 6 February.

Ukeje EU (1999). Productivity in the Agricultural Sector, Central Bank of http://w.cenbank.org/OUT/PUBLICATIONS/OCCASIONALPAPERS/ RD/2000/ABE-00-8.PDF 
Venkatraman N (1989). Strategic Orientation of Business Enterprises: The Construct, Dimensionality, and Measurement, Management Science 35(8).

Wang F, Chich-Jen S, Mei-Ling T (2010). Effect of leadership style on organizational performance as viewed from human resource management strategy, Afr. J. Bus. Manage. 4(18):3924-3936.

Ward PT, Bickford DJ, Leong GK (1996). Configurations of manufacturing strategy, Business Strategy, Environemtn and Structure, J. Manage. 22(4):597-626.

Wissema JG, Van Der Pol HW, Messer HM (1980). Strategic management archetypes, Strat. Manage. J. 1(1):37-47.
Wright P, Pringle CD, Kroll MJ (1992). Strategic Management: Text and Cases, Boston: Allyn and Bacon.

Yang B, Watkins K, Marsick V (2004). The Construct of the Learning Organization: Dimensions, Measurement, and Validation, Hum. Resour. Dev. Q. 15(1).

Zhou K, Yim C, Tse D (2005). The Effects of Strategic Orientations on Technology- and Market-Based Breakthrough Innovations, J. Market. 69:42-60. 